\title{
TINJAUAN HUKUM PIDANA TERHADAP PENGGUNA JASA PROSTITUSI ONLINE
}

\author{
Sri Husnulwati \\ Universitas PGRI Palembang \\ srihusnulwati05@gmail.com
}

\begin{abstract}
Looking at the articles in the Criminal Code, there are no articles that can be used to ensnare users of commercial sex services or commercial sex workers themselves. If referring to the law, of course, the targeted parties are only brokers and pimps. This study tries to see how the criminal law foundation can be used to ensnare users of online prostitution services. This research is a type of legal research which is also referred to as empirical legal research. The results of this research are, (1) Law No. 11 of 2008 concerning Information and Electronic Transactions is not appropriate to be used to deal with complex prostitution issues, (2) Law Number 44 of 2008 on Pornography does not explain specifically about users of online prostitution services, so in this case the Act cannot ensnare service users in the practice of online prostitution.
\end{abstract}

Keywords: Service Users, Online Prostitution, Criminal Law

\begin{abstract}
Abstrak
Melihat pasal-pasal yang ada dalam Kitab Undang-undang Hukum Pidana, tidak ada pasal yang dapat digunakan untuk menjerat pengguna jasa seks komersial maupun pekerja seks komersial itu sendiri. Jika merujuk Undang-undang tentu pihak yang disasar hanya calo dan germo. Penelitian ini mencoba melihat bagaimana landasan hukum pidana yang dapat dipakai untuk menjerat pengguna jasa prostitusi online. Penelitian ini merupakan jenis penelitian hukum yang juga disebut sebagai penelitian hukum empiris. Adapun hasil dari penelitian ini adalah, (1) Undang-undang No. 11 Tahun 2008 tentang Informasi dan Transaksi Elektronik tidaklah tepat digunakan untuk menanggulangi permasalahan prostitusi yang kompleks, (2) Undang-undang Nomor 44 tahun 2008 tentang Pornografi sama sekali tidak menjelaskan mengenai pengguna jasa prostitusi online secara khusus, sehingga dalam hal ini Undang-undang tersebut tidak dapat menjerat pengguna jasa dalam praktek prostitusi online.
\end{abstract}

\section{Kata Kunci : Pengguna Jasa, Prostitusi Online, Hukum Pidana}

\section{PENDAHULUAN}

Kemajuan teknologi dan informasi dewasa ini berdampak pada perubahan sosial, ekonomi dan budaya yang menuju pada pembentukan masyarakat modern. Dampak adanya teknologi dibidang informasi dan komunikasi dipastikan dapat merubah suatu Negara menjadi maju apabila Negara tersebut dapat mengolah, memanfaatkan media tersebut secara bijak dan bertanggung jawab. Tetapi apa yang akan terjadi apabila sebuah Negara yang memiliki media ini tidak dapat memanfaatkan dan mengolahnya dengan bijak dan bertanggung jawab. Maka perkembangan tersebut bak pisau bermata dua, perkembangan media interaksi berbasis internet juga memiliki sisi negatif apabila
Negara tersebut tidak dapat mengolah dan memanfaatkannya dengan baik. ${ }^{1}$

Pada perkembangannya, dengan ditemukannya komputer sebagai produk ilmu pengetahuan dan teknologi, terjadilah konvergensi antara teknologi telekomunikasi, media dan komputer. Konvergensi antara teknologi komunikasi, media dan komputer menghasilkan sarana baru yang disebut dengan internet. Internet telah memberikan sesuatu yang sama sekali baru pada umat manusia.

Dengan internet manusia dapat melakukan aktivitas layaknya di dunia nyata. Manusia dapat melakukan berbagai aktivitas di sana seperti

\footnotetext{
1 Dewi Bunga , 2012, Prostitusi Cyber, Udayana University Press: Denpasar, hal. 1.
}

Volume 17 Nomor 2. Bulan Mei 2019 
Sri Husnulwati, Tinjauan Hukum Pidana Terhadap Pengguna Jasa Prostitusi Online, halaman 132139

ngobrol, kongkow-kongkow, transaksi bisnis dan lain sebagainya. Internet seakan membentuk suatu realitas baru yang menjadikannya realitas kehidupan manusia secara dikotomis menjadi real life (kehidupan nyata) dan virtual life (kehidupan maya). ${ }^{2}$

Pelanggaran kesusilaan termasuk di dalamnya cyberporn dan prostitusi dengan menggunakan sarana elektronik atau internet.

Dalam hal ini cyberporn berasal dari kata cyber dan porn. Cyber lebih erat hubungannya terhadap media baru atau online yang menggunakan jaringan internet untuk penggunaannya. Sedangkan porn atau Pornografi, katanya (dari bahasa Yunani pornographia secara harafiah tulisan tentang atau gambar tentang pelacur,kadang kala juga disingkat menjadi penggambaran tubuh manusia atau perilaku seksual manusia secara terbuka (eksplisit) dengan tujuan membangkitkan birahi (gairah seksual).

Pemerintah Indonesia tidak secara tegas melarang adanya praktekpraktek prostitusi. Dikatakan tidak tegas karena pengaturan mengenai tindak pidana prostitusi online tidak adanya mengatur ketentuan tentang hukuman bagi pengguna jasa seks komersial. Sehingga mereka yang menggunakan jasa pekerja seks komersialpun dapat dengan leluasa tanpa takut terjerat sanksi hukum pidana. Di dalam Kitab Undang-undang Hukum Pidana ketentuan yang berhubungan dengan masalah prostitusi sangat sedikit dan sederhana, yaitu Pasal 290, Pasal 297 dan Pasal 506 KUHP. Ketentuan ini tidak dapat digunakan terhadap pengguna jasa prostitusi itu secara tegas, karena ketentuan ini hanya berlaku terhadap pelaku dan pengguna yang telah menikah,

2 Abdul Wahid dan Mohammad Labib, 2010, Kejahatan Mayantara (Cyber Crime), PT Refika Aditama: Bandung, hal. 7.

http://ekosupriyanto50.blogspot.com/2013/04/pengert ian-cyberporn.html diakses pada tanggal 25 Maret 2019 Pukul 14.26 WIB. penyedia fasilitas dan penerima keuntungan atau yang disebut mucikari atau germo.

\section{PEMBAHASAN}

\section{A. Konsep Prostitusi Online}

Prostitusi online berasal dari dua kata yang masing-masing dapat berdiri sendiri yakni prostitusi dan online. Prostitusi adalah istilah yang sama dengan prostitusi. Prostitusi menurut Soerjono Soekanto dapat diartikan sebagai suatu pekerjaan yang bersifat menyerahkan diri kepada umum untuk melakukan perbuatan-perbuatan seksual dengan mendapat upah. ${ }^{4}$

Kata terakhir dari istilah prostitusi online menggambarkan tempat dimana aktivitas ini dilakukan. Online merupakan istilah yang digunakan orang untuk menyatakan sesuatu yang berhubungan dengan internet atau dunia maya. Dengan demikian prostitusi online adalah kegiatan menawarkan jasa pelayanan seksual melalui dunia maya.

Adapun beberapa pengertian online, sebagai berikut :

Online adalah terhubung, terkoneksi, aktif dan siap untuk operasi, dapat berkomunikasi dengan atau dikontrol oleh komputer. Online ini juga bisa diartikan sedang menggunakan jaringan, terhubung dalam jaringan, satu perangkat dengan perangkat lainnya yang terhubung sehingga bisa saling berkomunikasi. $^{5}$

Pada dasarnya pengertian online adalah terhubung dengan internet. Sejak internet menjadi semakin familiar di semua lapisan masyarakat, mereka banyak yang memanfaatkannya sehingga muncullah berbagai toko online yang menawarkan berbagai macam barang yang kita butuhkan. ${ }^{6}$

\footnotetext{
4 SoerjonoSoekanto, 2005, Sosiologi Suatu Pengantar, Raja Grafindo Persada: Jakarta, hal. 374.

http://aguswiraguna.blogspot.com/2012/11/pengertia n-onlinewebsitesosial-media.html diakses tanggal 25 Maret 2019 Pukul. 14.05 WIB.

http://pitikkedu.blogspot.com/2012/09/pengertianonline.html diakses tanggal 25 Maret 2019 Pukul. 14.05 WIB..
} 
Sri Husnulwati, Tinjauan Hukum Pidana Terhadap Pengguna Jasa Prostitusi Online, halaman 132139

$\begin{array}{lrr}\begin{array}{l}\text { Internet merupakan } \\ \text { jaringan }\end{array} & \text { sekumpulan } \\ \text { menghubungkan sompter } & \begin{array}{r}\text { yang } \\ \text { situs }\end{array} & \text { akademik, } \\ \text { pemerintah, komersial, } & \text { organisasi } \\ \text { maupun perorangan. } & \text { Internet } \\ \text { menyediakan akses untuk layanan } \\ \text { telekomunikasi dan sumberdaya } \\ \text { infromasi untuk jutaan pemakainya } \\ \text { yang tersebar di seluruh dunia. }\end{array}$

Internet seakan membentuk suatu realitas baru yang menjadikan realitas kehidupan manusia terbagi secara dikotomis menjadi kehidupan nyata dan kehidupan maya. Internet merupakan aktivitas yang sulit dilakukan di dunia nyata dapat dengan mudah dilakukan di dunia maya.

Layanan internet meliputi komunikasi langsung (E-mail, Chat), diskusi (Usenet, News, E-mail, Milis), sumberdaya informasi yang terdistribusi (World wide web, Gopher), remote login dan lalu lintas file (Telnet, FTP), dan aneka layanan lainnya. ${ }^{8}$

Kemajuan teknologi yang merupakan hasil budaya manusia di samping membawa dampak positif, dalam arti dapat didayagunakan untuk kepentingan umat manusia juga membawa dampak negatif terhadap perkembangan manusia dan peradabannnya. Dampak negatif yang dimaksud adalah yang berkaitan dengan dunia kejahatan. J.E. Sahetapy telah menyatakan dalam tulisannya, bahwa kejahatan erat kaitannya dan bahkan menjadi sebagian dari hasil budaya itu sendiri. Ini berarti semakin tinggi tingkat budaya dan semakin modern suatu bangsa, maka semakin modern pula kejahatan itu dalam bentuk, sifat dan cara pelaksanaannya. ${ }^{9}$ Secara garis besar, kejahatan yang berkaitan dengan teknologi informasi dapat dibagi menjadi dua bagian besar. Pertama, kejahatan yang bertujuan merusak atau menyerang sistem atau jaringan komputer. Dan kedua, kejahatan yang menggunakan komputer

7 Abdul Wahid dan Mohammad Labib, 2010, Kejahatan Mayantara (Cyber Crime), PT Refika Aditama: Bandung, Hal 24.

8 Ibid.

9 Ibid., hal. 26. atau internet sebagai alat bantu dalam melancarkan kejahatan. ${ }^{10}$

Dalam Pembahasan mengenai prostitusi online ini membahas mengenai praktek prostitusi atau prostitusi dengan menggunakan media internet atau online sebagai sarana transaksi bagi mereka pekerja seks komersial dan yang ingin menggunakan jasanya. Jika ingin kita perdalam maknanya maka pengertian dari prostitusi online adalah transaksi prostitusi yang menggunakan media internet sebagai sarana penghubung antara pekerja seks komersial dengan yang ingin menggunakan jasanya. Jadi internet hanya sebagai sarana penunjang atau penghubung saja.

\section{B. Konsep Pengguna Jasa}

Pengguna jasa merupakan gabungan dari dua kata yaitu pengguna dan jasa. Pengguna adalah orang yang menggunakan sesuatu 44, sedangkan jasa atau layanan adalah aktivitas ekonomi yang melibatkan sejumlah interaksi dengan konsumen atau dengan barang-barang milik, tetapi tidak menghasilkan transfer kepemilikan. ${ }^{11}$

Para ahli memiliki pandangan tersendiri terhadap pengertian jasa, yaitu:

1) Phillip Kotler: jasa adalah setiap tindakan atau unjuk kerja yang ditawarkan oleh salah satu pihak ke pihak lain yang secara prinsip intangibel dan tidak menyebabkan perpindahan kepemilikan apapun. Produksinya bisa terkait dan bisa juga tidak terikat pada suatu produk fisik.

2) Adrian Payne: jasa adalah aktivitas ekonomi yang mempunyai sejumlah elemen (nilai atau manfaat) intangibel yang berkaitan dengannya, yang melibatkan sejumlah interaksi dengan konsumen atau dengan barang-barang milik, tetapi tidak menghasilkan transfer kepemilikan. Perubahan daiam kondisi bisa saja muncul dan produksi suatu jasa bisa memiliki atau bisa juga tidak mempunyai kaitan dengan produk fisik.

\footnotetext{
10 Ibid., hal. 27.

11 http://www.deskripsi.com/p/pengguna diakses pada tanggal 25 Maret 2019 pukul 23.15 WIB.
} 
3) Christian Gronross: jasa adalah proses yang terdiri atas serangkaian aktivitas intangible yang biasanya (namun tidak harus selalu) terjadi pada interaksi antara pelanggan dan karyawan jasa dan atau sumber daya fisik atau barang dan atau sistem penyedia jasa, yang disediakan sebagai solusi atas masalah pelanggan". Interaksi antara penyedia jasa dan pelanggan kerap kali terjadi dalam jasa, sekalipun pihak-pihak yang terlibat mungkin tidak menyadarinya. Selain itu, dimungkinkan ada situasi di mana pelanggan sebagai individu tidak berinteraksi langsung dengan perusahaan jasa. $^{12}$

Berdasarkan beberapa definisi di atas, maka jasa pada dasarnya adalah sesuatu yang memiliki ciri-ciri sebagai berikut:

1) Sesuatu yang tidak berwujud, tetapi dapat memenuhi kebutuhan konsumen.

2) Proses produksi jasa dapat menggunakan atau tidak menggunakan bantuan suatu produk fisik.

3) Jasa tidak mengakibatkan peralihan hak atau kepemilikan.

4) Terdapat interaksi antara penyedia jasa dengan pengguna jasa. ${ }^{13}$

\section{Tinjauan Yuridis Pengguna Jasa Prostitusi Online Berdasarkan Kitab Undang-undang Hukum Pidana}

Melihat pasal-pasal yang ada dalam Kitab Undang-undang Hukum Pidana, tidak ada pasal yang dapat digunakan untuk menjerat pengguna jasa seks komersial maupun pekerja seks komersial itu sendiri. Apabila kita lihat pasal 296 dan pasal 506 Kitab Undang-undang Hukum Pidana tidak ditujukan kepada pengguna jasa seks komersial maupun pekerja seks komersial, akan tetapi ditujukan kepada germo dan calo seks komersial saja. Pasal 281 Kitab Undangundang Hukum Pidana sangat sulit untuk diterapkan kepada pengguna jasa seks komersial, karena dalam kenyataanya pengguna jasa seks komersial melakukan

$$
{ }_{13}^{12} \text { Ibid }
$$

http://irwansahaja.blogspot.com/2013/05/pengertianjasa-karakteristik-jasa-dan.html diakses pada tanggal 26 Maret 2019 pukul 08.48 WIB hubungan kelamin dengan secara tertutup. Pasal 284 Kitab Undang-undang Hukum Pidana masih bersifat diskriminatif, karena ancaman dapat diberlakukan kepada perempuan yang melakukan perbuatan zina baik yang bersuami ataupun yang tidak bersuami dapat dipidanakan, sementara ketentuan untuk laki-laki yang belum beristri tidak dapat dikenakan pidana.

Dari semua persoalan tersebut bila dilihat pada masa sekarang ini, perlu menyempurnakan atau membuat peraturan perundang-undangan hukum pidana atau Kitab Undang-undang Hukum Pidana yang baru karena yang berlaku sekarang ini merupakan peninggalan penjajah belanda yang sudah tidak sesuai lagi dengan perubahan jaman. Oleh karena itu tidak tepat jika melakukan penertiban prostitusi online dengan menggunakan pasal yang ada dalam Kitab Undang-undang Hukum Pidana, karena tidak dapat lagi memfasilitasi permasalahan prostitusi online di Indonesia dan karena transaksi prostitusi online merupakan kejahatan yang terintegrasi dengan cara dan modus operandi yang berteknologi tinggi. Kitab Undang-undang Hukum Pidana sekarang ini memang sudah layaknya direvisi, karena dengan merevisi Kitab Undangundang Hukum Pidana berarti memperkuat dan memperjelas segala tindakan yang bersifat kesusilaan.

\section{Tinjauan Yuridis Pengguna Jasa Prostitusi Online Berdasarkan Undang-Undang Nomor 11 Tahun 2008 Tentang Informasi dan Transaksi Elektronik}

Pada dasarnya undang-undang itu lahir sebelum permasalahan timbul, harapannya untuk melindungi masyarakat dari permasalahan yang akan terjadi. Pada kenyataannya Undang-undang tidak mampu untuk melihat dan mengetahui permasalahan yang akan terjadi dimasa yang akan datang. Berkembangannya lingkungan, budaya dan teknologi membuat perubahan tata kehidupan didalam masyarakat. Kemajuan teknologi yang semakin pesat merupakan faktor penyebab perubahan terbesar dalam tata kehidupan masyarakat tersebut, sehingga semua dapat dipermudah dengan kehadiran teknologi. 
Kehadiran teknologi ini dan yang paling pesat berkembang adalah internet. Tentu saja dengan harapan untuk mempermudah kehidupan dalam berkegiatan sehari-hari, namun pemerintah kurang tanggap akan kehadiran teknologi internet ini, akibatnya kehadiran teknologi internet ini banyak salah digunakan, contohnya seperti dalam praktek prostitusi melalui jaringan intenet. Baru sejak 2003 pemerintah berinisiatif membuat undang-undang yang mengatur tentang kegiatan melalui media internet ini dengan nama RUU informasi komunikasi dan transaksi elektronik yang sekarang menjadi Undang-Undang Nomor 11 Tahun 2008 Tentang Informasi dan Transaksi Elektronik (UU ITE).

UU ITE itu sendiri mulai dirancang pada bulan maret 2003 oleh Kementerian Negara Komunikasi dan Informasi (KOMINFO), pada mulanya RUU ITE diberi nama undang-undang informasi komunikasi dan transaksi elektronik oleh Departemen Perhubungan, Departemen Perindustrian, Departemen Perdagangan, serta bekerja sama dengan Tim dari universitas yang ada di Indonesia yaitu Universitas Padjajaran (UNPAD), Institut Teknologi Bandung (ITB) dan Universitas Indonesia (UI). ${ }^{14}$

Hadirnya Undang-undang Nomor 11 Tahun 2008 tentang Informasi dan Transaksi Elektronik ini diharapkan dapat memberikan batasan-batasan terhadap aktifitas yang dilakukan melalui media internet salah satunya adalah praktek prostitusi online. Undang-undang ini berisi tentang peraturan dan sanksi terhadap tindakan kriminal di dunia maya secara pidana. Peristiwa pidana itu adalah rangkaian perbuatan manusia yang bertentangan dengan Undang-undang atau peraturan perundangan lainnya, terhadap perbuatan yang mana diadakan tindakan penghukuman. $^{15}$

14

http://eltrations.blogspot.com/2010/11/orem-ipsumdolor-sit-amet-consectetur.html diakses pada tanggal 25 Maret 2019 Pukul 14.55 WIB.

15 Mr. Tresna, 1959. Asas-Asas Hukum Pidana, PT. Tiara: Jakarta, hal. 27.
Sebelum dibentuknya undang-undang Informasi dan Transaksi Elektronik ini, praktek prostitusi dengan media internet sudah banyak terjadi, walaupun tidak secara terang-terangan.

Orang dapat dikatakan mempunyai kesalahan, jika pada waktu melakukan perbuatan pidana, dilihat dari segi masyarakatnya dapat tercela karenanya, yaitu kenapa melakukan perbuatan yang merugikan masyarakat padahal mampu untuk mengetahui dampak buruk perbuatan tersebut dan mengetahui bahwa perbuatan tersebut melanggar ketentraman atau nilai-nilai dalam masyarakat, dan karenanya dapat bahkan harus menghindari perbuatan yang sedemikian itu. ${ }^{16}$

Undang-Undang Nomor 11 tahun 2008 merupakan suatu upaya pemerintah untuk mengimbangi perkembangan ilmu pengetahuan dan teknologi di bidang teknologi informasi dan transaksi elektronik yang semakin pesat. Semakin berkembangnya teknologi menyebabkan semakin merebaknya bisnis prostitusi karena dapat memanfaatkan sarana internet dalam bertransaksi dan penawaran prostitusi. Walaupun telah diundangkannya undang-undang tersebut belum berlaku efektif dalam menjerat dan menanggulangi bisnis prostitusi online.

Undang-Undang Nomor 11 Tahun 2008 Tentang Informasi dan Transaksi Elektronik (UU ITE) tidak menyebutkan kata prostitusi dalam semua pasalnya. Kecuali dalam pasal 27 yang berisikan tentang perbuatanperbuatan yang dilarang, menyebutkan kata kesusilaan yang menyangkut kepada hal-hal yang berbau pornografi. Isi dalam pasal 27 UU ITE yaitu sebagai berikut:

(1) Setiap Orang dengan sengaja dan tanpa hak mendistribusikan dan/atau mentransmisikan dan/atau membuat dapat diaksesnya Informasi Elektronik dan/atau Dokumen Elektronik yang memiliki muatan yang melanggar kesusilaan. 
Sri Husnulwati, Tinjauan Hukum Pidana Terhadap Pengguna Jasa Prostitusi Online, halaman 132139

(2) Setiap Orang dengan sengaja dan tanpa hak mendistribusikan dan/atau mentransmisikan dan/atau membuat dapat diaksesnya Informasi Elektronik dan/atau Dokumen Elektronik yang memiliki muatan perjudian.

(3) Setiap Orang dengan sengaja dan tanpa hak mendistribusikan dan/atau mentransmisikan dan/atau membuat dapat diaksesnya Informasi Elektronik dan/atau Dokumen Elektronik yang memiliki muatan penghinaan dan/atau pencemaran nama baik.

(4) Setiap Orang dengan sengaja dan tanpa hak mendistribusikan dan/atau mentransmisikan dan/atau membuat dapat diaksesnya Informasi Elektronik dan/atau Dokumen Elektronik yang memiliki muatan pemerasan dan/atau pengancaman.

Pada pasal 27 Undang-undang Nomor 11 Tahun 2008 tentang Informasi dan Transaksi Elektronik (ITE) ayat (1) menyebutkan kata kesusilaan yang maksudnya menyangkut pada hal-hal bersifat pornografi. Pasal ini dimaksudkan larangan bagi setiap orang untuk mendistribusikan, mentransmisikan, membuat dapat diaksesnya informasi dan/atau dokumen elektronik yang memiliki muatan yang melanggar kesusilaan. Muatan yang terdapat pada pasal ini hanya membatasi penyedia layanan seks komersial dan pemilik website semata. Sehingga dalam ketentuan yang terdapat pada pasal 27 ayat (1) Undang-undang Nomor 11 Tahun 2008 ini juga tidak ditemui larangan dan pembatasan bagi pengguna jasa layanan seks komersial.

Pada pasal 27 ayat (1) tersebut, menyebutkan :

"Setiap Orang dengan sengaja dan tanpa hak mendistribusikan dan/atau mentransmisikan dan/atau membuat dapat diaksesnya Informasi Elektronik dan/atau Dokumen Elektronik yang memiliki muatan yang melanggar kesusilaan".
Subyek hukum yang dituntut pertanggungjawaban pidananya dalam Undang-undang ini hanyalah "pemilik" website prostitusi online saja, yakni sebagai orang yang mendistribusikan atau mentransmisikan atau membuat dapat diaksesnya situs-situs porno atau prostitusi online tersebut. Kemudian yang dimaksud dengan "yang memiliki muatan melanggar kesusilaan" pada pasal tersebut adalah jika memenuhi unsur-unsur sebagai berikut:

a. Tidak mengandung nilai melainkan hanya mengandung unsur yangmembangkitkan nafsu birahi bagi yangmelihat, memperhatikan ataupun mendengarnya.

b. Bertentangan dengan nilai-nilai atau norma-norma yang berlaku dalam masyarakat. $^{17}$

Berdasarkan penjelasan di atas dijelaskan bahwa yang dimaksud prostitusi online yang diatur pada Undang-undang Nomor 11 Tahun 2008 tentang Informasi dan Transaksi Elektronik tersebut adalah situssitus yang menampilkan atau menyediakan muatan-muatan melanggar kesusilaan yang tujuannya hanya untuk menghasilkan uang dengan cara menampilkan gambar wanita pekerja seks komersial, tanpa tujuan lainnya seperti untuk keperluan pendidikan, terapi pengobatan, dan lain sebagainya. Ketentuan mengenai sanksi dalam pasal 27 Undangundang Nomor 11 Tahun 2008 tentang Informasi dan Transaksi Elektronikini termuat, yaitu pada Pasal 45 ayat (1) tentang Ketentuan Pidana:

"Setiap Orang yang memenuhi unsur sebagaimana dimaksud dalam Pasal 27 ayat (1), ayat (2), ayat (3), atau ayat (4) dipidana dengan pidana penjara paling lama 6 (enam) tahun dan/atau denda paling banyak Rp.1.000.000.000,00 (satu miliar rupiah)."

Pasal ini mengancam penjatuhan pidana bagi setiap orang yang melakukan beberapa kejahatan, yang salah satunya pasal 27 ayat (1) mengenai prostitusi online dengan pidana penjara maksimal 6 tahun dan/atau denda

17 Lutfan Muntaqo, 2006. Porno: Definisi dan Kontroversi, Jagad Pustaka: Yogyakarta, hal. 39. 
maksimal 1 miliar rupiah. Dalam Undangundang ini tidak dijelaskan mengenai sanksi pidana bagi para pengguna jasa dalam tindak pidana prostitusi online. Undang-undang inipun tidak dapat menjerat pelaku pengguna jasa layanan seks komersial prostitusi online, sehingga Undangundang inipun tidaklah tepat digunakan untuk menanggulangi permasalahan prostitusi yang kompleks. Seharusnya Undang-undang ini mengatur sanksi pidana untuk seluruh subyek dalam tindak pidana prostitusi online, karena pengguna jasa layanan seks komersial prostitusi online adalah bagian dari subyek tindak pidana prostitusi dan pengguna jasa layanan seks komersial prostitusi online melibatkan transaksi elektronik dalam melakukan kegiatan prostitusinya.

\section{Tinjauan Yuridis Pengguna Jasa Prostitusi Online Berdasarkan UndangUndang Nomor 44 Tahun 2008 Tentang Pornografi}

Sebagaimana dijelaskan pada bahasan sebelumnya, bahwa pornografi merupakan akar dari muncul dan berkembangnya bisnis prostitusi online di Indonesia, karena pornografi merupakan rangkaian materi seksualitas yang dapat membangkitkan hasrat seksual dan dapat menimbulkan berkembangnya pornoaksi dalam masyarakat. Pengertian pornografi sendiri berdasarkan pasal 1 butir 1 ketentuan umum Undangundang Nomor 44 Tahun 2008 tentang Pornografi yaitu :

"Pornografi adalah hasil karya manusia yang memuat materi seksualitas dalam bentuk gambar, sketsa, ilustrasi, foto, tulisan, suara, bunyi, gambar bergerak, animasi, kartun, syair, percakapan, atau bentuk-bentuk pesan komunikasi lain dan/atau melalui media yang dipertunjukkan di depan umum dan/atau dapat membangkitkan hasrat seksual serta melanggar nilai-nilai kesusilaan dalam masyarakat dan/atau menimbulkan berkembangnya pornoaksi dalam masyarakat"

Pekerja Seks Komersial merupakan salah satu bagian yang dijadikan sebagai objek yang terdapat dalam muatan materi seksualitas pornografi. Oleh karena itu, undang-undang ini juga memuat tentang larangan penyebarluasan jasa pornografi. Jasa pornografi berdasarkan pasal 1 butir 13 adalah :

"Jasa pornografi adalah segala jenis layanan pornografi yang disediakan oleh perorangan ataupun badan hukum atau yang lainnya, melalui telepon, televisi kabel, internet, dan/atau komunikasi elektronik lainnya, dengan cara memesan atau berlangganan barangbarang pornografi yang dapat diperoleh secara langsung dengan cara menyewa, meminjam, atau membeli"

Bicara mengenai prostitusi sebenarnya sangat terkait dengan persoalan kesetaraan gender. Larangan terhadap penyediaan stok Pekerja Seks Komersial sebenarnya tidak akan mampu meruntuhkan bisnis prostitusi yang melibatkan banyak pihak.

Bila menurut logika bisnis/ekonomi, maka bila seorang penjual/penyedia jasa tidak ada barang dan tidak ada konsumen yang mencari barang tersebut, maka tak satupun orang akan menjadi penjual/penyedia jasa atas barang tersebut, kecuali penjual itu mempunyai kemampuan menjual yang inovatif yaitu menciptakan pasar kreatif, yaitu membuat orang tergila-gila untuk membeli barang/jasa yang disediakan. Tetapi sekali lagi, pilihan terakhir tentunya ada di pihak konsumen atau ketersediaan barang itu sendiri. Kalau konsumen mengatakan tidak, maka sebagus atau sekreatif apapun si penjual melakukan inovasi, maka barang/jasanya pasti tidak akan terjual atau dibeli oleh konsumen. ${ }^{18}$

Karenanya, untuk menghapus transaksi bisnis gelap terbesar di dunia (selain senjata illegal dan narkoba) ini, yang di-pressure mestinya bukan penawaran, tapi permintaan. Jadi, seumpama ingin benar-benar menghargai perempuan dan berniat

18

http://hukum.kompasiana.com/2014/02/27/bisnisseks-narkotik-hukum-yang-salah-kaprah636148.html diakses pada tanggal 25 Maret 2019 pukul 11.54 WIB 
Sri Husnulwati, Tinjauan Hukum Pidana Terhadap Pengguna Jasa Prostitusi Online, halaman 132139

menghapuskan prostitusi, alih-alih melarang stok baru, yang lebih efektif adalah menghukum pembeli.

Undang-undang Nomor 44 Tahun 2008 tentang Pornografi yang diharapkan mampu membatasi materi seksualitas dalam tindak pidana prostitusi online tidak dapat menjerat pengguna jasa prostitusi online, undangundang ini hanya membatasi pihakpihak yang dapat dikenakan sanksi yaitu Sanksi bagi pelaku penyedia jasa terdapat dalam pasal 30, sanksi bagi pemilik server terdapat dalam pasal 33, sanksi bagi pekerja seks komersial terdapat dalam pasal 34, dan sanksi bagi mucikari terdapat dalam pasal 35 .

Ketentuan dalam Undang-undang Nomor 11 tahun 2008 tentang Informasi dan Transaksi Elektronik dan Undang-undang Nomor 44 tahun 2008 tentang Pornografi sama sekali tidak menjelaskan mengenai pengguna jasa prostitusi online secara khusus, sehingga kedua Undang-undang inipun tidak dapat menjerat pengguna jasa dalam praktek prostitusi online. Seharusnya diharapkan Undang-undang tersebut dapat menjerat subyek dalam prostitusi online secara keseluruhan, agar terciptanya suatu keadilan dan kepastian hukum.

Setelah melihat penjelasan Undangundang Nomor 44 tahun 2008 tentang Pornografi sama sekali tidak menjelaskan mengenai pengguna jasa prostitusi online secara khusus, sehingga dalam hal ini Undang-undang tersebut tidak dapat menjerat pengguna jasa dalam praktek prostitusi online. Hal itu dikarenakan pembuat kebijakan sepertinya tidak duduk bersama para ahli yang benar-benar mengerti tentang pembahasan undang-undang tersebut. Seharusnya diharapkan Undang-undang tersebut dapat menjerat subyek dalam prostitusi online secara keseluruhan, agar terciptanya suatu keadilan dan kepastian hukum.

\section{PENUTUP}

Merujuk pada penjelasan mengenai landasan hukum dalam menjerat pengguna jasa prostitusi online, maka dapat disimpulkan beberapa hal sebagai berikut :

1. Undang-undang No. 11 Tahun 2008 tentang Informasi dan Transaksi
Elektronik tidak dapat menjerat pelaku pengguna jasa layanan seks komersial prostitusi online, sehingga Undangundang inipun tidaklah tepat digunakan untuk menanggulangi permasalahan prostitusi yang kompleks. Seharusnya Undang-undang ini mengatur sanksi pidana untuk seluruh subyek dalam tindak pidana prostitusi online, karena pengguna jasa layanan seks komersial prostitusi online adalah bagian dari subyek tindak pidana prostitusi dan pengguna jasa layanan seks komersial prostitusi online melibatkan transaksi elektronik dalam melakukan kegiatan prostitusinya.

2. Setelah melihat penjelasan Undangundang Nomor 44 tahun 2008 tentang Pornografi sama sekali tidak menjelaskan mengenai pengguna jasa prostitusi online secara khusus, sehingga dalam hal ini Undang-undang tersebut tidak dapat menjerat pengguna jasa dalam praktek prostitusi online. Hal itu dikarenakan pembuat kebijakan sepertinya tidak duduk bersama para ahli yang benarbenar mengerti tentang pembahasan undang-undang tersebut.

\section{DAFTAR PUSTAKA}

Bunga, Dewi. 2012. Prostitusi Cyber. Denpasar: University Press.

Kansil, C.S.T. 1989. Pengantar Ilmu Hukum dan Tata Hukum Indonesia. Jakarta: Balai Pustaka.

Muntaqo, Lutfan. 2006. Porno: Definisi dan Kontroversi. Yogyakarta: Jagad Pustaka.

Soekanto, Soerjono. 2005. Sosiologi Suatu Pengantar. Jakarta: Raja Grafindo Persada.

Tresna, Mr. 1959. Asas-Asas Hukum Pidana. Jakarta: PT. Tiara.

Wahid, Abdul dan Mohammad Labib. 2010. Kejahatan Mayantara (Cyber Crime). Bandung: PT Refika Aditama.

Undang-Undang Nomor 11 Tahun 2008 Tentang Informasi dan Transaksi Elektronik

UndangUndang Nomor 44 Tahun 2008 Tentang Pornografi 
Sri Husnulwati, Tinjauan Hukum Pidana Terhadap Pengguna Jasa Prostitusi Online, halaman 132139

http://hukum.kompasiana.com/2014/02/27/bis nis-seks-narkotik-hukum-yang-salahkaprah 636148.html diakses pada tanggal 25 Maret 2019 pukul 11.54 WIB

media.html diakses tanggal 25 Maret 2019 Pukul. 14.05 WIB.

http://pitikkedu.blogspot.com/2012/09/penger tian-online.html diakses tanggal 25 Maret 2019 Pukul. 14.05 WIB..

http://ekosupriyanto50.blogspot.com/2013/04/ pengertian-cyberporn.html diakses pada tanggal 25 Maret 2019 Pukul 14.26 WIB.

http://aguswiraguna.blogspot.com/2012/11/pe ngertian-onlinewebsitesosial- 